\title{
Single-phase line start permanent magnet synchronous motor. Rotor construction and stator winding optimization
}

\author{
MacieJ GWOŹDZIEWICZ, JAN ZAWILAK \\ Institute of Electrical Machines, Drives and Measurements \\ Wroclaw University of Technology \\ e-mail: \{maciej.gwozdziewicz/jan.zawilak\}@pwr.wroc.pl
}

(Received: 17.06.2012, revised: 16.01.2013)

\begin{abstract}
The paper deals with construction of single-phase line start permanent magnet synchronous motor. Circuit-field single-phase line start permanent magnet synchronous motor model based on the mass production single-phase induction motor was applied in Maxwell program. Various rotor constructions were taken into account. Influence of the rotor construction on the motor properties was examined. Running motor performances were examined.
\end{abstract}

Key words: permanent magnet, single-phase motor, synchronous motor, high efficiency motor

\section{Introduction}

Among many literature and laboratory researches the trend towards the rapid development of the permanent magnet synchronous motors are strongly noticeable. This motor type construction is similar to the induction motor construction [2-4]. The main difference between them is permanent magnets in the synchronous motor rotor. The rotor cage in the permanent magnet synchronous motor enables the motor to inherent start and stabilizes the motor running. Line start permanent magnet synchronous motors have very good running properties and average starting properties $[5,6]$. Their typical application are fans or pumps. Nowadays, the medium power line start permanent magnet synchronous motors are built, tested and being introduced into production [1]. The most recommended solution of the excitation of permanent magnet synchronous motor is $\mathrm{NdFeB}$ neodymium magnets, which are characterized by high energy density and high remanence induction. However, limited amount of these elements results in rapid increase in the price of neodymium magnets which forces manufacturers of synchronous motors with permanent magnets to reduce the volume of permanent magnets in the designed motors. 
Single-phase line start permanent magnet synchronous motor construction is quite similar to three-phase line start permanent magnet synchronous motor construction. The main problem in this type of motor is relatively narrow rotor yoke so the volume in the rotor for the permanent magnets installation is very limited. It causes additional difficulties in designing of single-phase line start permanent magnet synchronous motors.

\section{Model construction}

Two dimensional field-circuit models of the single-phase line start permanent magnet synchronous motor were applied in Maxwell ver. 14 program. The models are based on the mass production single-phase induction motor Seh 80-4B type with $P_{n}=750 \mathrm{~W}, U_{n}=230 \mathrm{~V}$, $f_{n}=50 \mathrm{~Hz}, n_{n}=1370 \mathrm{rpm}$. Neodymium magnet N38SH type with $B_{r}=1.24 \mathrm{~T}$ and $H_{c b}=990 \mathrm{kA} / \mathrm{m}$ was chosen for the excitation of the synchronous motor. Single-phase induction motor was changed into single-phase line start permanent magnet synchronous motor by replacement standard squirrel-cage rotor with squirrel-cage permanent magnet rotor.

Permanent magnets shapes were changed saving their volume. Rotor bars were kept without any change. It follows that costs of permanent magnets are the same but more complicated shape needs more time during permanent magnets installation into the motor rotor.

Circuit part of the motor model is shown in Figure 1 and field parts of the motor models are shown in Figure 2.

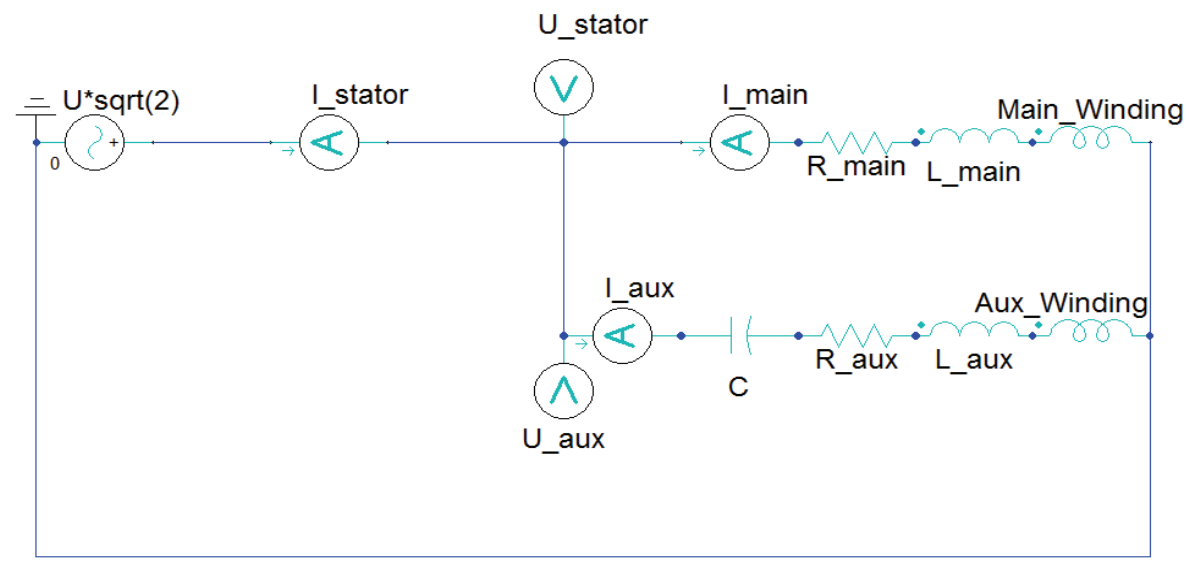

Fig. 1. Circuit part of the single-phase line start permanent magnet synchronous motor models

\section{EMF investigation}

Influence of the permanent magnets assembly in the single-phase line start permanent magnet synchronous motor on the EMF magnitude was examined. EMF THD coefficient was calculated according to the formula (1): 


$$
T H D_{E}=\frac{\sqrt{\sum_{2}^{40}\left(E_{h}\right)^{2}}}{E_{1}} .
$$

Obtained results are shown in Figure 3 a), b), c).

a)

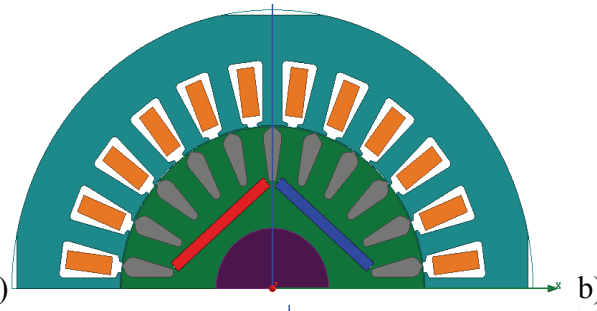

c)

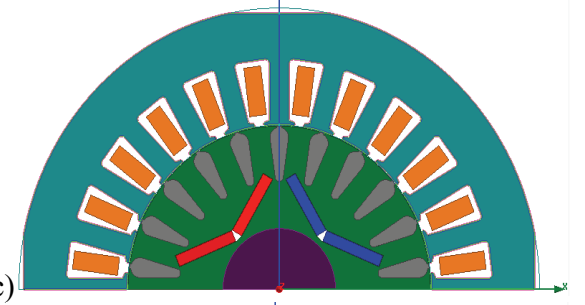

b)

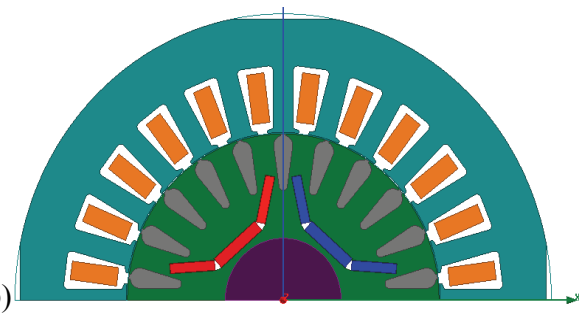

d)

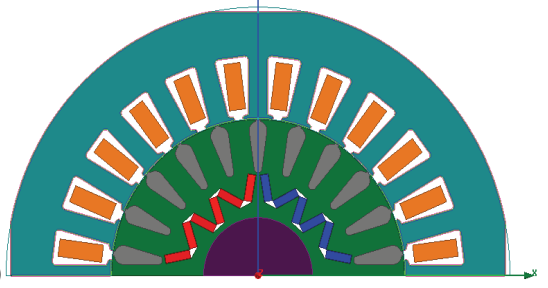

e)

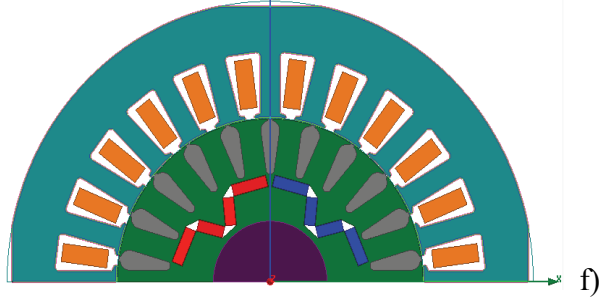

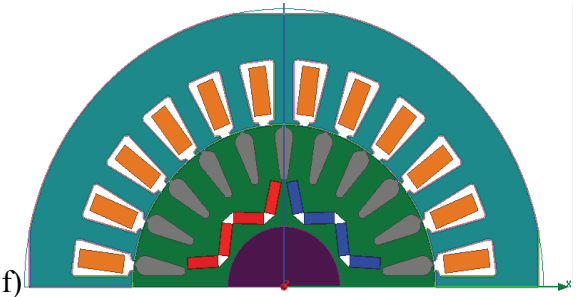

Fig. 2. Field circuit parts of the single-phase line start permanent magnet synchronous motor models with different permanent magnet shapes: a) - b) $\boldsymbol{U}$, c) $\boldsymbol{V}$, d) $\boldsymbol{V} \boldsymbol{V} \boldsymbol{V}$, e) $-\boldsymbol{V}-$, f) $\boldsymbol{W}$

According to the results shown in the Figure 3 a), b), c) permanent magnets assembly in single-phase line start permanent magnet synchronous motor has significant influence on the EMF magnitude, its THD coefficient and cogging torque.

For further investigation only $\boldsymbol{U}$ shape was taken into account due to the highest magnitude of the EMF and the lowest magnitude of the EMF THD coefficient.

\section{Auxiliary winding parameters}

In Maxwell program single-phase line start permanent magnet synchronous motor with permanent magnets assembled in $\boldsymbol{U}$ shape was examined. Running capacitor capacitance and number of the auxiliary winding were changed. The criterion was to obtain the highest motor efficiency for the load power $(0.86-0.91) P_{n}=1100 \mathrm{~W}$. The power $P_{n}=1100 \mathrm{~W}$ is next step in this motor classification relatively to $P_{I M}=750 \mathrm{~W}$. 
Range (0.86-0.91) of the rated power was taken to maximum motor efficiency examination due to assumption that motor rated power is higher than load power about (10-15\%) according to the formula for the motor selection for the fan/pump type load (2):

$$
P_{\text {motor }}=k \cdot \frac{Q \cdot \Delta p}{\eta}
$$

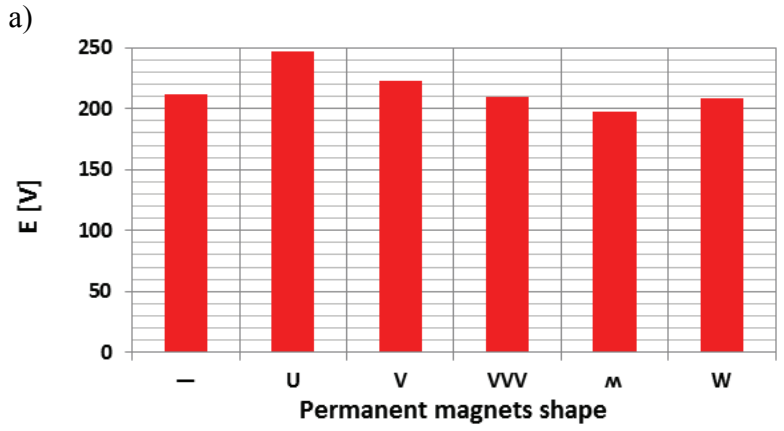

b)

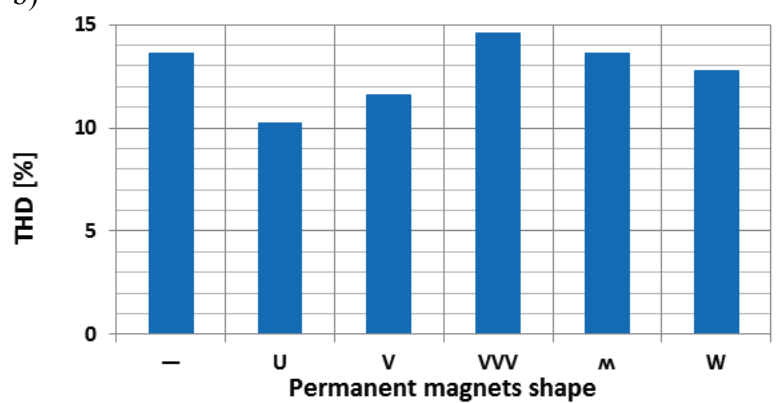

c)

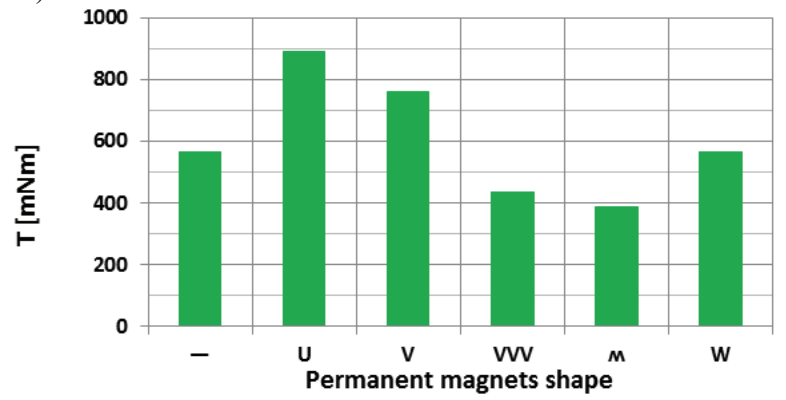

Fig. 3. Influence of the permanent magnets shape: a) on the $1^{\text {st }}$ EMF harmonic magnitude, b) on the THD coefficient, c) on the cogging torque

where: $P_{\text {motor }}-$ motor power, $k$ - reserve coefficient $(k=1.1-1.15), Q$ - flow rate, $\Delta p$ - static pressure, $\eta-$ fan/pump efficiency. To calculate efficiency core loss was added to the input power of the motor. Maxwell program calculates core loss but it does not take it into account during input power calculations. 
Low power line start permanent magnet synchronous motors have higher rated power than induction motors with the same size [8]. Due to that assumption the single-phase line start permanent magnet synchronous motor $P_{n}=1100 \mathrm{~W}$ seems to be reasonable. An example of obtained results is show in Figures 4 and 5.

According to the obtained results the highest motor efficiency was obtained for the $C_{r u n}=50 \mu \mathrm{F}$ and for $z_{a u x}=40$ turns. The single-phase line start permanent magnet synchronous motor performances were compared with the induction motor performances in Table 1 and in Figures 6 and 7.

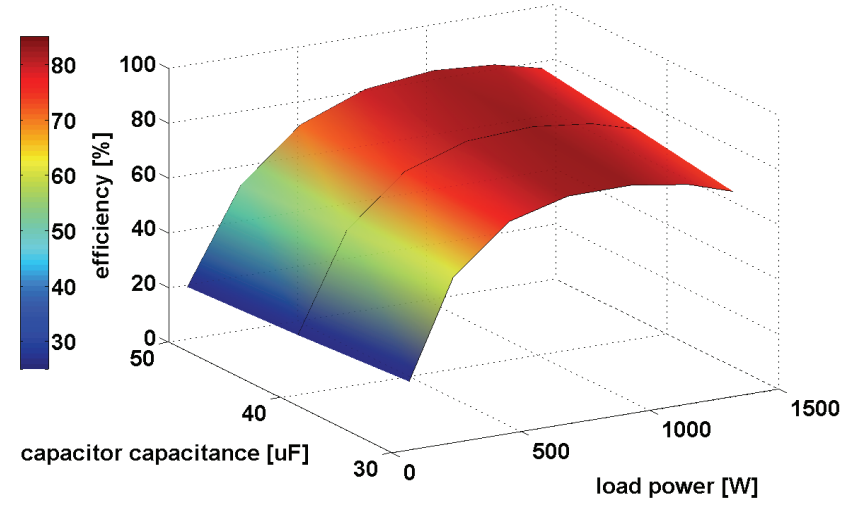

Fig. 4. Influence of the running capacitor capacitance on the single-phase line start permanent magnet synchronous motor efficiency curve for number of the auxiliary winding turns $z_{\text {aux }}=40$ turns

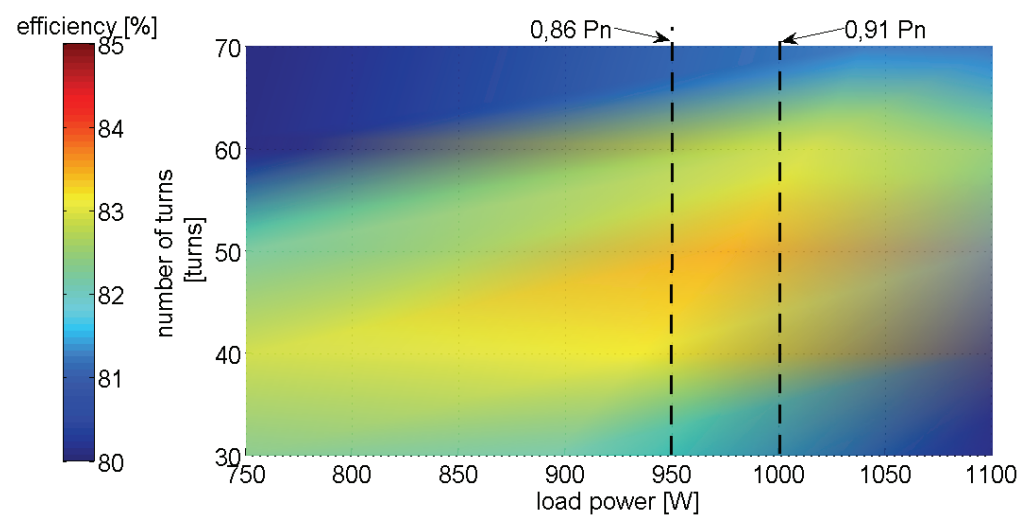

Fig. 5. Influence of the number of the stator winding turns on the single-phase line start permanent magnet synchronous motor efficiency curve for the capacitor capacitance $C=50 \mu \mathrm{F}$

Obtained results presented in Table 1 and in Figures 6 and 7 show clearly advantages of single-phase line start permanent magnet synchronous motor. These results show that singlephase line start permanent magnet synchronous motors good proposition for the further development of the electrical machines. Current densities in the main and auxiliary winding of the 
Table 1. Comparison of single-phase line start permanent magnet synchronous motor and single-phase induction motor

\begin{tabular}{c|c|c|c}
\hline & & IM & PMSM \\
\hline$P$ & $\mathrm{~kW}$ & 0.75 & 1.1 \\
\hline$\eta$ & $\%$ & 73 & 84 \\
\hline $\cos \varphi$ & - & 0.92 & 0.95 \\
\hline$I$ & $\mathrm{~A}$ & 4.9 & 6.1 \\
\hline$j_{\text {main }}$ & $\mathrm{A} / \mathrm{mm}^{2}$ & 8.1 & 8.1 \\
\hline$j_{\text {aux }}$ & $\mathrm{A} / \mathrm{mm}^{2}$ & 6.4 & 4.6
\end{tabular}

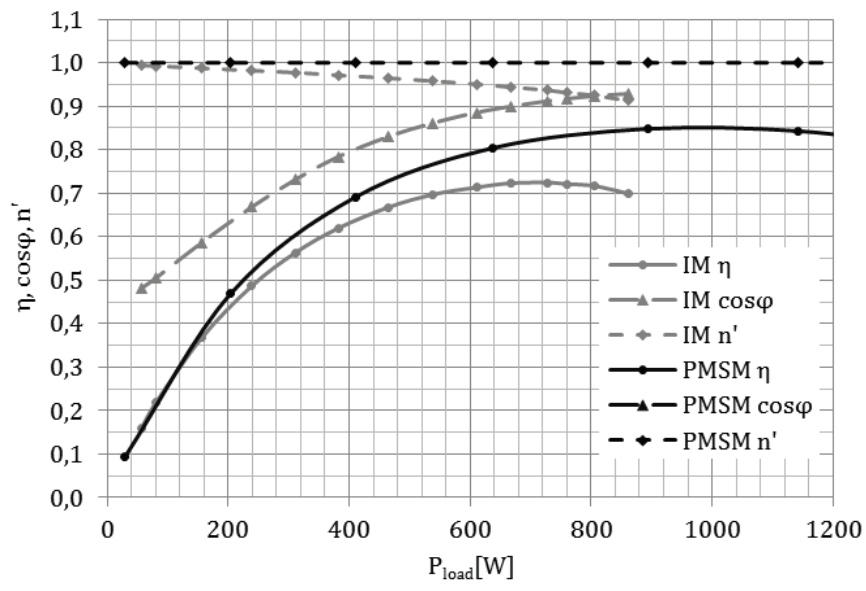

Fig. 6. Comparison of line start single-phase permanent magnet synchronous motor and single-phase induction motor performances

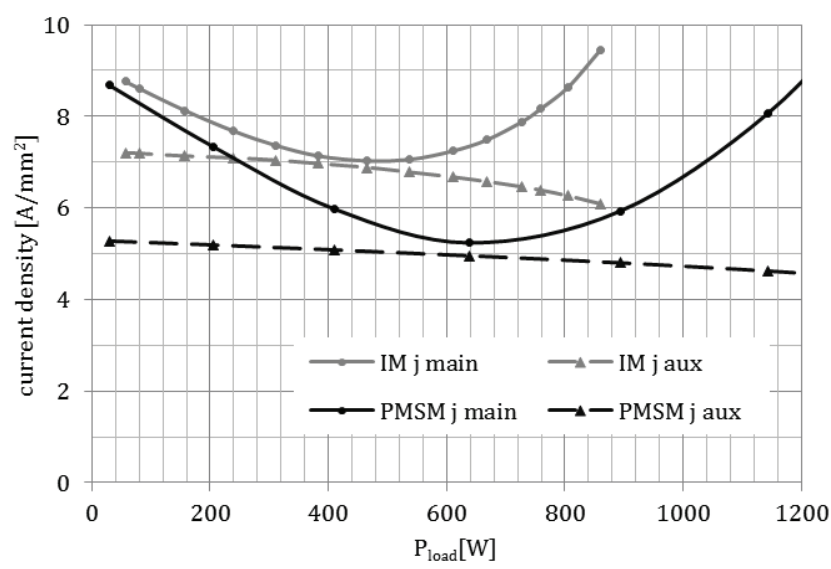

Fig. 7. Current densities in main and auxiliary winding of the line start single-phase permanent magnet synchronous motor and single-phase induction motor 
single-phase line start permanent magnet synchronous motor do not exceed the corresponding current densities of the induction motor so there is no hazard of overheating during the motor running.

\section{Starting properties}

LSPMSM are good solution for pumps or fans because of good running properties and poor starting properties [6]. Typical pump or fan load characteristic is shown in Figure 8.

Fig. 8. Typical pump/fan load characteristic

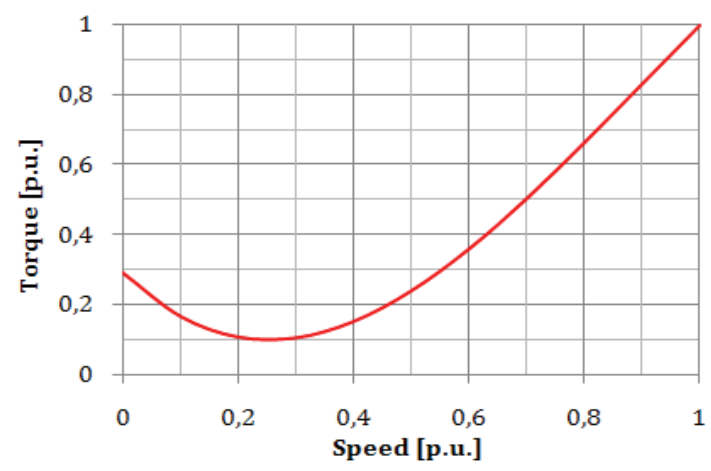

To investigate starting properties of the SPLSPMSM pump/fan load characteristic was assumed. The rated load torque was equal to the SPLSPMSM rated torque and moment of inertia of the whole drive system was assumed to be ten times greater that the SPLSPMSM moment of inertia according to the formula (4):

$$
J=10 \cdot J_{\text {motor }}=0.01 \mathrm{kgm}^{2} .
$$

For the chosen optimal solution of the SPLSPMSM two start-capacitors were applied: $200 \mu \mathrm{F}$ and $250 \mu \mathrm{F}$. The results of starting simulation are presented in Figures 9, 10 and 11 .

Fig. 9. SPLSPMSM starting speeds

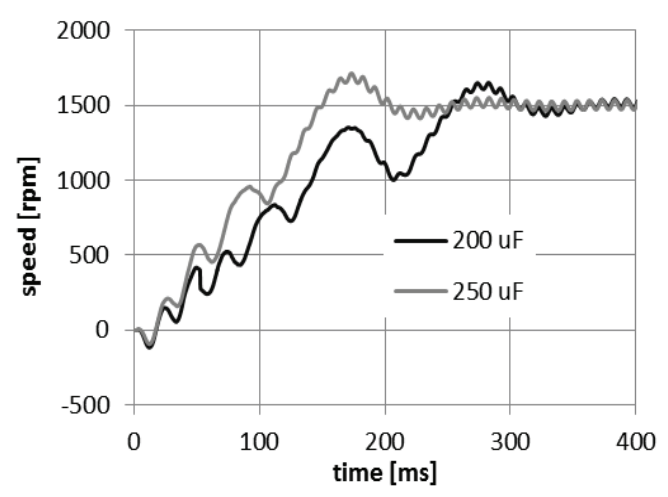


According to the obtained starting simulation results it follows that increase of capacitance of the start-capacitor improves starting properties of SPLSPMSM and makes better ability to synchronization. Moreover, increase of capacitance of the start-capacitor causes a little increase of the starting current.

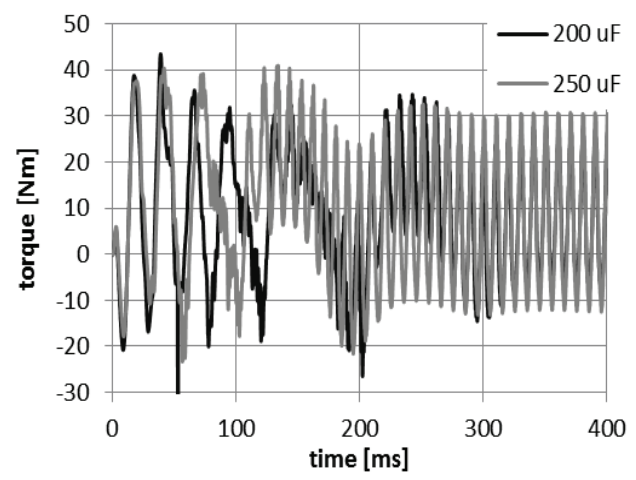

Fig. 10. SPLSPMSM starting torques

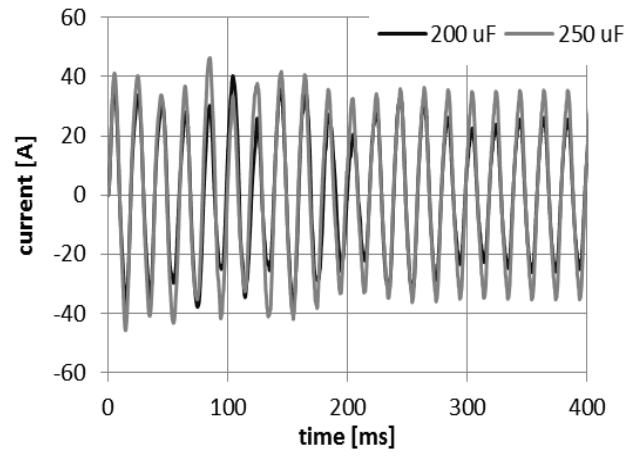

Fig. 11. SPLSPMSM starting currents

\section{Conclusions}

Permanent magnets assembly in the single-phase line start permanent magnet synchronous motor rotor has significant influence on the motor properties. The goals of this type of electric motor designing are limitation of the permanent magnets volume and simultaneously achieving high motor performances. The main problem during single-phase line start permanent magnet synchronous motor is relatively narrow rotor yoke what is restriction in permanent magnets assembly.

Running properties of the single-phase line start permanent magnet synchronous motor are significantly better than running properties of the single-phase induction motor. Starting properties of the single-phase line start permanent magnet synchronous motor can be improved by increase of the running capacitor capacitance, which must be switched-off after synchronization by a time relay. 


\section{References}

[1] Aliabad A.D., Mirsalim, M., Ershad, N.F., Line-Start Permanent-Magnet Motors: Significant Improvements in Starting Torque, Synchronization, and Steady-State Performance. IEEE Transactions on Magnetics 46(12): 4066-4072 (2010).

[2] Ebrahimi B.M., Faiz J., Hasanpour-Isfahani A., Impacts of rotor slots on interior permanent magnet motors performance. Przegląd Elektrotechniczny 3 (2011).

[3] Fei W., Luk P., Ma J., Shen J.X., Yang G., A High-Performance Line-Start Permanent Magnet Synchronous Motor Amended From a Small Industrial Three-Phase Induction Motor. IEEE Transaction on Magnetics 45(10): 4724-4727 (2009).

[4] Feng X., Liu L., Kang J., Zhang Y., Super premium efficient line start-up permanent magnet synchronous motor. 2010 XIX International Conference on Electrical Machines (ICEM), Rome, Italy, 6-8 September 2010, p. 1-6 (2010).

[5] Fengbo Q., Zhipeng L., Shukang Ch., Weili L., Calculation and simulation analysis on starting performance of the high-voltage line-start PMSM. (ICCASM), 2010 International Conference on Computer Application and System Modeling 3: V3-198-V3-202 (2010).

[6] Guang Yang, Jun Ma, Jian-Xin Shen, Yu Wang, Optimal design and experimental verification of a line-start permanent magnet synchronous motor. ICEMS 2008. International Conference on Electrical Machines and Systems, p. 3232-3236 (2008).

[7] Gwoździewicz M., Zawilak J., Influence of the permanent magnets arrangement on the single-phase line start permanent magnet synchronous motor performances. Prace Naukowe Instytutu Maszyn, Napędów i Pomiarów Elektrycznych Politechniki Wrocławskiej. Studia i Materiały (2012).

[8] Gwoździewicz M., Zawilak J., Influence of the rotor construction on the single-phase line start permanent magnet synchronous motor performances. Przegląd Elektrotechniczny 10 (2011).

[9] Gwoździewicz M., Zawilak J., Jednofazowy silnik synchroniczny z magnesami trwatymi o rozruchu bezpośrednim. Konstrukcje magnetowodu. Maszyny Elektryczne. Zeszyty Problemowe. 95 (2012).

[10] Gyu-Hong Kang; Jin Hur; Hyuk Nam; Jung-Pyo Hong; Gyu-Tak Kim., Analysis of irreversible magnet demagnetization in line-start motors based on the finite-element method. Magnetics, IEEE Transactions on Volume 39(3), Part: 1 (2003).

[11] Kurihara K., Kubota T., Nitawaki D., Rotor Design for High Starting Performance of a Self-Starting Single-Phase Permanent-Magnet Motor. Przegląd Elektrotechniczny 7b (2012).

[12] Kurihara K., Wakui G., Kubota T., Steady-state performance analysis of permanent magnet synchronous motors including space harmonics. IEEE Transactions on Magnetics 30(3), (1994).

[13] Liang Fang, Lee, B.H., Jung-Pyo Hong, Hyuk Nam., Estimation of Magnet Reduction in SinglePhase Line-Start Permanent Magnet Synchronous Motor. Industry Applications Society Annual Meeting, IAS 2009, IEEE (2009).

[14] Lin D., Zhou P., Lambert N., Starting Winding Optimization in Single-Phase. Electrical Machines (ICEM), 2010 XIX International Conference

[15] Lu Q., Huang X., Ye Y. Fang Y., Experiment and analysis of high power line-start PM motor. Przegląd Elektrotechniczny 2 (2012).

[16] Pisek P., Stumberger B., Marcic T., Virtic P., Performance comparison of double and single rotor permanent magnet machine. Przegląd Elektrotechniczny 3 (2011).

[17] Popescu M., Miller T.J.E., McGilp M.I., Torque behavior of 1-phase permanent magnet AC motor, Energy Conversion. IEEE Transactions on 21 (2006).

[18] Qing Zhao, Xiulian Wang, Shenbo Yu, Dong Zhang, Zhongliang An, Renyuan Tang, Study and design for large line-start permanent magnet synchronous motors. Sixth International Conference on Electrical Machines and Systems, 2003. ICEMS 2003, 1: 132-133 (2003).

[19] Szewczyk K., Golisz R., Walasek T., Kucharczyk Z., The influence of an air gap around the permanent magnets with the flux concentrator in Permanent Magnet Synchronous Motor with Internal Magnetic Circuits. Przegląd Elektrotechniczny 12b (2011).

[20] Yang G., Ma J., Shen J.X., Wang Y., Optimal design and experimental verification of a line-start permanent magnet synchronous motor. 2008. ICEMS 2008. International Conference on Electrical Machines and Systems, p. 3232-3236 (2008). 
[21] Zhao H., Luo Y., Ren H.W., Peter B., A Complete Model for Iron Losses Prediction in Electric Machines Including Material Measurement, Data Fitting, FE Computation and Experimental Validation. Przegląd Elektrotechniczny 5b (2012).

[22] Zhong H., Wang X., Wang D., Analysis and Design of a New Type High-efficiency Single-phase Induction Motor Based on Negative Sequence Magnetic Field Compensation. Electrical Machines and Systems, 2008. ICEMS (2008). 